J. Perinat. Med. 10 (1982) 23

\section{The relationship of prolactin in cord blood, gestational age and respiratory compliance after birth in newborn infants}

\author{
E. Schober, G. Simbruner, H. Salzer, P. Husslein, J. Spona
}

Division of Neonatology, Department of Pediatrics, Department of Gynecology I, University of Vienna, Austria

\section{Introduction}

Despite specialized and sophisticated therapy the survival of newborns especially premature newborns still depends on whether the baby develops respiratory distress syndrome (RDS) or not. The development of RDS in newborns is due to deficiency of surfactant which is necessary for alveolar stability.

Investigations of the recent years have analysed the possible influence of several hormones on lung maturation and production of surfactant.

Recent investigations $[2,3,4,7]$ indicate that also prolactin may influence surfactant production respectively development of RDS directly. All three study groups independently found an association between the incidence of RDS and low cord blood prolactin levels, although they could not clarify if prolactin in cord blood is only an indicator of maturity in general or a directly influencing factor for lung maturation.

The aim of our study was to analyse the relationship between prolactin and respiratory compliance post partum as an index of lung maturity.

\section{Patients and methods}

We studied 36 newborns. 29 of them were healthy and had no signs of RDS (Gestational age 30 to 41 weeks).

The other 7 newborns showed symptoms of RDS, radiological signs of hyaline membrane desease (HMD) III to IV and needed respirator treatment

\section{Curriculum vitae}

Dr. E. SCHOBER was born in 1948 in Kirchdorf a.d. Krems, upper Austria. After primary- and secondary school she finished HighSchool (BLBA in Linz) in 1967. 1967 to 1973 she studied Medicine in the University of Vienna. Since October 1974 she is working at the Univ. Childrens Hospital in Vienna with special interest in paediatric endocrinology.

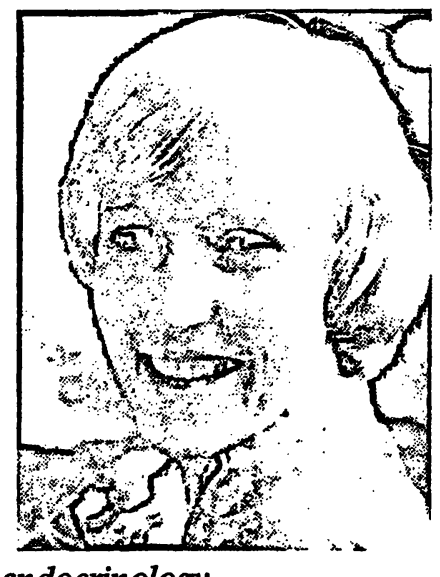

(Gestational age 28 to 31 weeks). 6 died and 1 survived.

The gestational age was determined by morphological criterias (PETRUSSA Score).

Mixed cord blood samples were obtained immediately after cord clamping, serum was separated and frozen until assay. Prolactin was measured by radioimmunoassay (Serono ${ }^{\circledR} \mathrm{Kit}$ ).

The compliance of the respiratory system was determined by the airway occlusion technique in the spontaneously breathing newborns during NON-REM sleep [8].

In the infants with RDS, intubated and ventilated, the respiratory compliance was determined by injecting a known amount of oxygen into the closed airway system and measuring the resulting airway pressure. For both methods apparatus and procedure are described in detail elsewhere [6]. 
All compliance measurements were done $160.6 \pm$ 57.8 minutes in the healthy and $156.7 \pm 46.4$ minutes after birth in the sick infants. Written parental consent for the investigation was obtained.

\section{Results}

In healthy newborns the prolactin levels in cord blood ranged from 56 to $670 \mathrm{ng} / \mathrm{ml}$. The cord blood prolactin was statistically significantly related to the gestational age (Fig. 1, $\mathrm{r}=0.62$, $\mathrm{p}<0.001$ ) but was not related to the compliance of the respiratory system (Fig. 2, $\mathrm{r}=0.22, \mathrm{n}$. s.).

In the seven newborns with RDS the prolactin values ranged from 39.6 to $168 \mathrm{ng} / \mathrm{ml}$. Their compliance values were much lower than those of the healthy newborns (Fig. 2).

Choosing the arbitrary cutoff value of $170 \mathrm{ng} / \mathrm{ml}$ prolactin in cord blood; we got one group with 7 RDS newborns and 5 healthy newborns. The group of healthy newborns had prolactin values of $107.2 \pm 39.9 \mathrm{ng} / \mathrm{ml}$ and respiratory compliance values of $1.95 \pm 0.25 \mathrm{ml} / \mathrm{cm} \mathrm{H}_{2} \mathrm{O}$, while ghe group of RDS newborns had prolactin levels of $68.6 \pm$ $44.4 \mathrm{ng} / \mathrm{ml}$ and compliance values of $0.63 \pm$ $0.28 \mathrm{ml} / \mathrm{cm} \mathrm{H}_{2} \mathrm{O}$. There was no statistically significant difference between these two groups in the prolactin values $(t=1.55$, n.s.), but their compliance values differed significantly $(\mathrm{t}=8.4$, $\mathrm{p}<0.001$ ).

\section{Discussion}

In accordance with other investigators we could show that fetal prolactin levels increase with gestational age (Fig. 1).

The prolactin values in cord blood at birth are distinctly higher than in maternal blood and decrease after a post partum rise during the first months of life to low levels which remain during the whole childhood. The physiological relevance of these high fetal values is still unclear [1].

The study groups of GLUCKMAN, HAUTH and SMITH suggested a direct stimulation of surfactant production by prolactin, based on their findings that a high incidence of RDS is associated with low prolactin levels in newborns $[2,4,7]$.

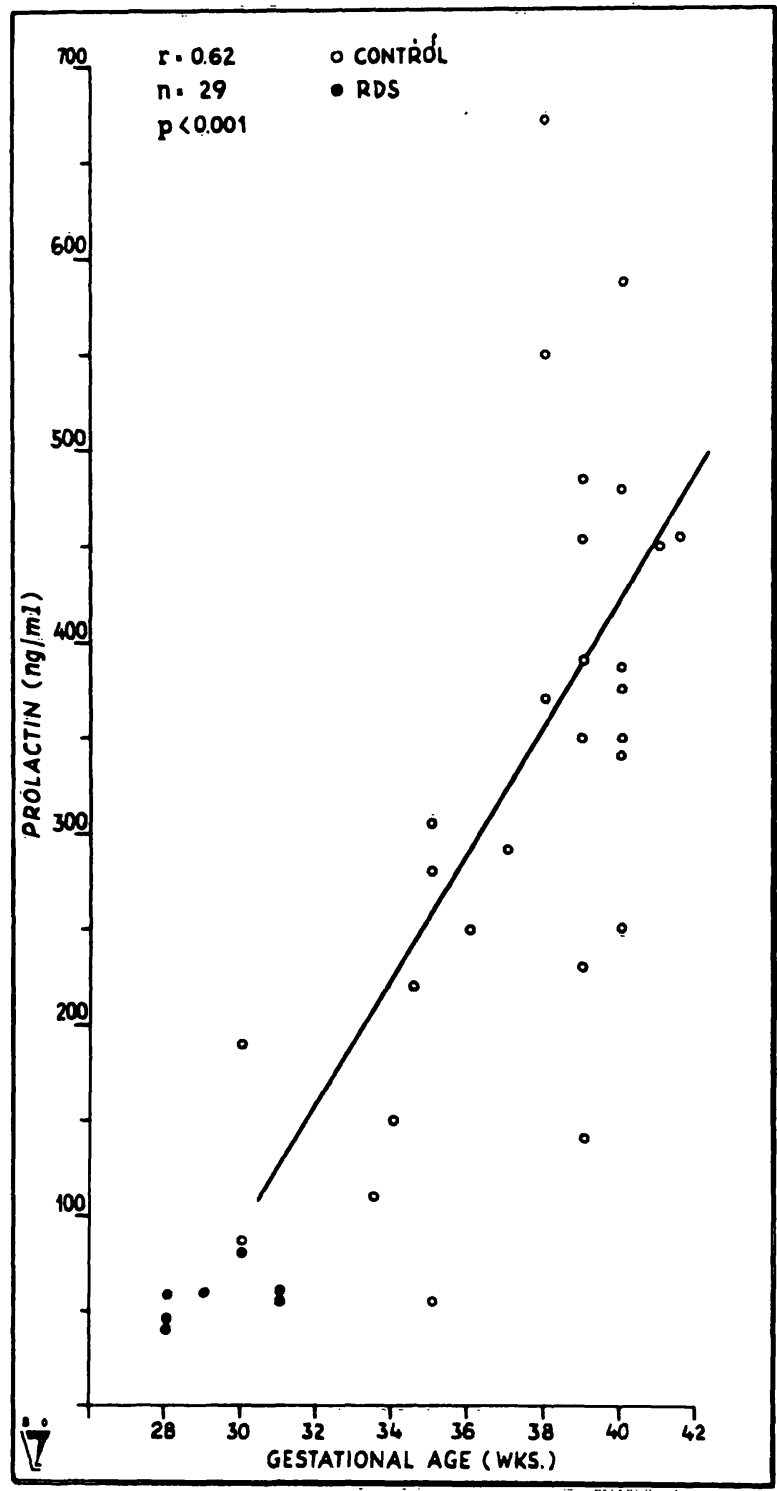

Fig. 1. Relationship between gestational age and cord blood prolactin in healthy newborns $(n=29)$. The prolactin levels of the RDS patients seem to be in continuation of the regression line of the healthy newborns without RDS.

Since RDS is only a clinical entity of symptoms influenced by several factors we used the measurement of respiratory compliance as an objective criteria for lung maturity. Though the respiratory compliance comprises the compliance of the lung and the thorax, it is in overwhelming part due to the lung compliance and only little influenced by thoracic compliance, which is about 10 times as high. Lung compliance reflectes the surfactant content [5] and by that lung maturation. 


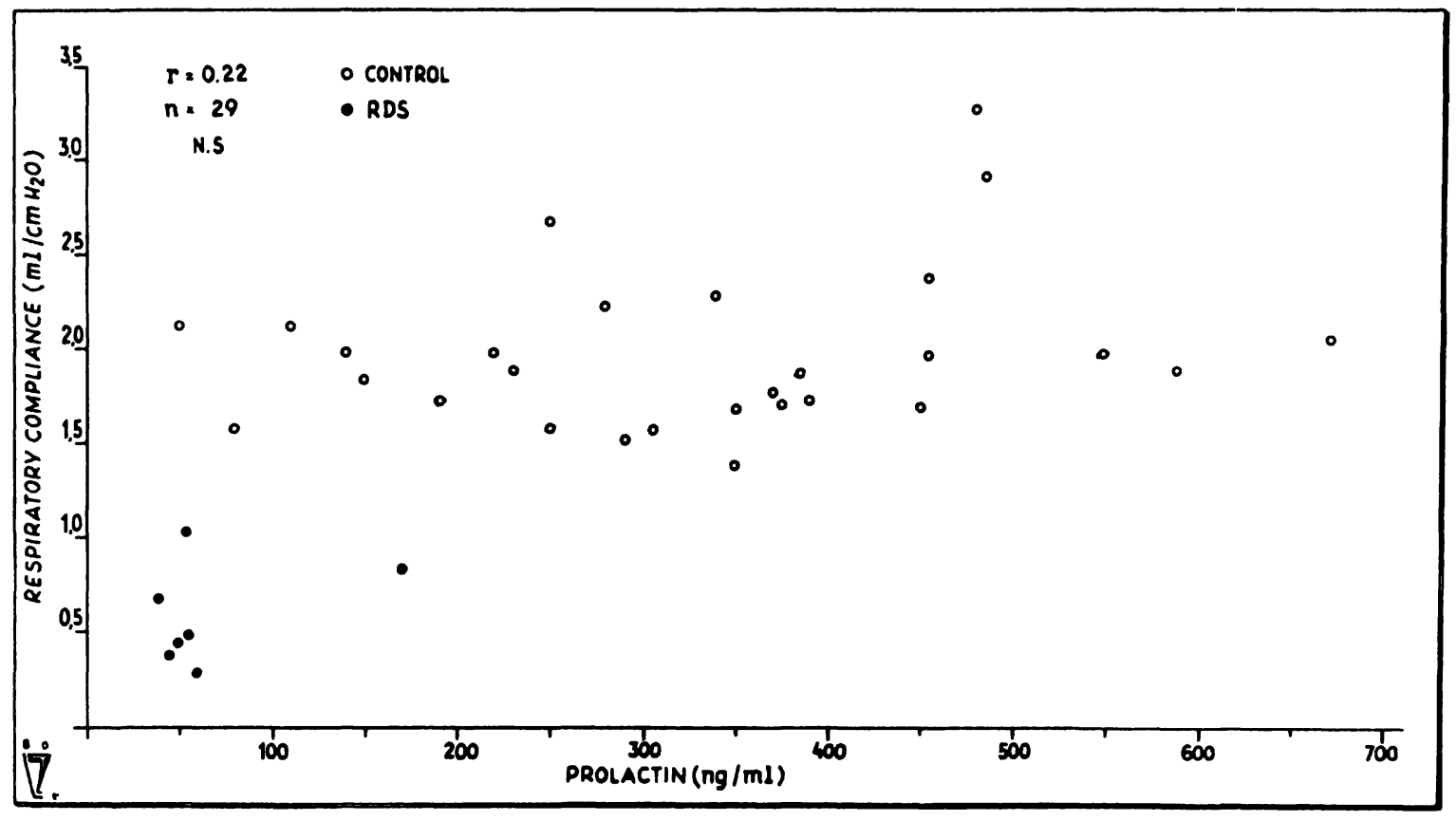

Fig. 2. Relationship between respiratory compliance and cord blood prolactin in healthy newborns $(n=29)$. RDS infants show distinctly lower compliance values.

If prolactin had a direct influence on lung maturation, there should be a close correlation between compliance and prolactin values in the cord blood especially in a homogenous group of healthy newborns. We did not find a correlation between prolactin and respiratory compliance in healthy newborns (Fig. $2, r=0.22$ n. s.). The prolactin values of our healthy newborns showed the same wide range $(56-670 \mathrm{ng} / \mathrm{ml})$ as observed in healthy newborns by Gluckman, HaUth, and Smith [2, $4,7]$.

The prolactin levels of the RDS patients in the study seem to be in continuation of the regression line for healthy newborns (Fig. 1) without RDS.
The lung compliance of the RDS newborns was distinctly lower than the respiratory compliance of the healthy newborns. We compared healthy and RDS newborns with cord blood prolactin below $170 \mathrm{ng} / \mathrm{ml}$. There was no significant difference in the mean prolactin values, but their respiratory compliance that means lung maturity differed significantly $(\mathrm{p}<0.001)$.

Therefore we conclude that prolactin levels in newborns are only associated with the gestational age i.e. the general maturation process and that prolactin does not have a direct influence on the specific lung maturation and surfactant content of the lung.

\section{Summary}

In 29 healthy newborns (gestational age 30-41 weeks) and 7 newborns with respiratory distress syndrome (gestational age 28-31 weeks) the prolactin levels in the cord blood and respiratory compliance was measured. Prolactin was determined by radioimmunoassay, the respiratory compliance was measured with the airway occlusion technique in spontanously breathing newborns and with injection of known volumes and measuring the airway pressure in newborns with ventilatory support.
In healthy newborns prolactin and gestational age were significantly correlated $(r=0.62, p<0.001)$, while prolactin did not correlate with respiratory compliance $(\mathrm{r}=0.22$, n. s.). Comparing 5 healthy newborns and the 7 RDS infants with prolactin values below $170 \mathrm{ng} / \mathrm{ml}$, there was no significant difference in the prolactin levels, but in the compliance values.

We conclude that prolactin does not directly influence lung maturation, but is associated with gestational age.

Keywords: Prolactin, respiratory compliance, respiratory distress syndrome. 
Zusammenfassung

Zusammenhang zwischen Prolactin im Nabelschnurblut, Gestationsalter und Compliance des respiratorischen Systems nach der Geburt

Ein positiver Einfluß des Prolactins auf die Lungenreifung wird in neueren Publikationen diskutiert.

Wir haben bei 29 gesunden Neugeborenen (Gestationsalter 30-41 Wochen) und 7 Neugeborenen mit Respiratory Distress Syndrome (Gestationsalter 28-31 Wochen) den Prolactinspiegel im Nabelschnurblut und die Compliance des respiratorischen Systems nach der Geburt gemessen. Prolactin wurde radioimmunologisch, die Compliance mit der Airway Occlusions Technik bei spontan atmenden Säuglingen bestimmt. Bei den beatmeten Neugeborenen wurde mit Injektion einer bestimmten Menge Luft der Druck in den Atemwegen gemessen.
:

Bei den gesunden Neugeborenen fanden wir eine signifikante Korrelation zwischen Prolactin und Gestationsalter $(\mathrm{r}=0,62, \mathrm{p}<0,001)$, während zwischen Prolactin und Compliance keine signifikante Beziehung nachgewiesen werden konnte ( $r=0,22, \mathrm{n}$.s.).

Die 7 Neugeborenen mit Respiratory Distress Syndrome und 5 gesunde Neugeborene mit Prolactinwerten unter $170 \mathrm{ng} / \mathrm{ml}$ unterschieden sich signifikant in ihren Compliancewerten nicht jedoch in den Prolactinspiegeln.

Auf Grund unserer Untersuchungsergebnisse besteht kein direkter Einfluß des Prolactins auf die Lungenreifung, sondern die Prolactinspiegel sind mit dem Gestationsalter assoziiert.

Schlüsselwörter: Prolactin, respiratorische Compliance, Respiratory Distress Syndrome.

Résumé

Relations entre la prolactine du sang du cordon, l'âge gestationnel et la compliance respiratoire après la naissance chéz les nouveau-nés

Dans la littérature récente une influence de la prolactine sur la maturation des poumons a été discutée. Nous avons déterminé la concentration de prolactine dans le sang du cordon ombilical ainsi que la compliance du système respiratoire chez 27 nouveau-nés sains (âge gestationnel de 30 à 41 semaines) et chez 7 nouveau-nés avec détresse respiratoire (âge gestationnel 18 à 31 semaines).

La prolactine a été mesurée par un radioimmunologie. La compliance respiratoire a été déterminée chez les enfants qui respiraient spontanément par la méthode d'occlusion des voies aériennes; et chez les enfants qui étaient ventilés par respirateur nous avons calculé la compliance respira- toire par mesure de la pression trachéale après injection d'un volume connu.

Chez les nouveau-nés sains, il y avait une corrélation significative entre l'âge gestationnel et la concentration de prolactine $(r=0,62, p<0,01)$, mais la concentration de la prolactine n'était pas correlée avec la compliance du système respiratoire $(\mathrm{r}=0,22$, n.s.). Comparant 5 nouveau-nés sains et les 7 enfants avec détresse respiratoire qui avaient une concentration de prolactine au-dessous de $170 \mathrm{ng} / \mathrm{ml}$, nous n'avons pas trouvé de différence significative entre les concentrations de prolactine bien que les compliances respiratoires aient été différentes.

Nous pouvons ainsi conclure que la concentration de prolactine dépend de l'âge gestationnel mais qu'elle n'a pas d'influence sur la maturation pulmonaire.

Mots-clés: Compliance respiratoire, prolactine, syndrôme de détresse respiratoire.

\section{Bibliography}

[1] BALlARD, P. L., P. D. GLUCKMAN, A. BREHIER, J. A. KitTerman, S. L. KAPLAN, A. M. RUDOLPH, M. M. GRUMBACH: Failure to detect an effect of prolactin on pulmonary surfactant and adrenal steroids in fetal sheep and rabbits. J. Clin. Invest. 62 (1978) 879

[2] GLUCKMAN, P. D., P. L. BALlARD, S. L. KAPLAN, G. C. LIGGINS, M. M. GRUMBACH: Prolactin in umbilical cord blood and the respiratory distress syndrome. J. Pediat. 93 (1978) 1011

[3] HAMOSH, M., P. HAMOSH: The effect of prolactin on the lecithin content of fetal rabbit lung. J. Clin. Invest. 59 (1977) 1002

[4] HAUTH, J. C., C. R. PARKER, P. C. MACDONALD, J. C. PORTER, J. M. JOHNSTON: A role of fetal prolactin in lung maturation. Obstet. and Gynec. 51 (1978) 81

[5] REYNOLDS, E. O. R., N. R. C. ROBERTON, J. S. WIGGLESWORTH: Hyaline membrane disease, respiratory distress and surfactant deficiency. Pediatrics 42 (1968) 758
[6] Simbruner, G., H. CORADEllo, G. LubEC, A. POLLAK, H. SALZER: Die Compliance des respiratorischen Systems bei gesunden und respiratorisch erkrankten Neugeborenen in den ersten Lebensstunden und ihr prognostischer Wert für den Einsatz von Atemhilfen. Klin. P[diatrie 192 (1980) 415

[7] SMITH, Y. F., D. K. MULLON, M. HAMOSH, J. W. SCALON, P. HAMOSH: Serum prolactin and respiratory distress syndrome in the newborn. Pediat. Res. 14 (1979) 93

[8] TAEUSCH, H. W., S. CARSON, jr., I. D. FRANTZ, J. MILIC-EMILI: Respiratory regulation after elastic loading and $\mathrm{CO}_{2}$ rebreathing in normal term infants. J. Pediat. 88 (1976) 102

Received June 1, 1981. Revised July 7, 1981. Accepted September 11, 1981

\author{
Dr. E. Schober \\ Universitätskinderklinik \\ Währinger Gürtel 74-76 \\ A-1090 Wien \\ Austria
}

